\title{
KEBERLANJUTAN TEKNOLOGI PENANGKAPAN IKAN CAKALANG (Katsuwonus pelamis) DI PERAIRAN TELUK BONE, SULAWESI SELATAN
}

\author{
Sustainability of Fishing Technologies of Skipjack Tuna (Katsuwonus pelamis) \\ in Bone Bay Waters, South Sulawesi
}

Oleh:

\author{
Achmar Mallawa 1, Faisal Amir1, Safruddin 1, Elsa Mallawa ${ }^{2}$ \\ 1FPIK, Universitas Makassar; achmar_mallawa@yahoo.co.id;faisal_unhas@yahoo.com; saruddinhasyim@gmail.com \\ 2 FPIK, Universitas Andi Djemma Palopo; elsamallawa@yahoo.com
}

Diterima: 22 September 2017; Disetujui: 26 April 2018

\begin{abstract}
The skipjack is one of important fishery commodities in Gulf of Bone waters, exploited by fishermen through the year using kinds of fishing gears such as pole and line, purse seine, traditional seine net, hand line, and predicted that some of these technologies were not sustainable. The objective of research was to analysis sustanaibility or environmental friendly of fishing technology of skipjack in Gulf of Bone waters, and has been done for six months, from January to June, 2017. Biology data of catch, fishing technic, and social economic of fishing unit of pole and line, purse seine, traditional seine net and hand line was collected directely by survey method. The sustainability or environmental friendly of fishing technologies be analyzed using 14 biology, technic, economic and social (Arimoto modified by Mallawa). Result that pole and line reach $76.88 \%$ of sustainability value, pole and line operated in $F A D 51.50 \%$, purse seine $51.25 \%$, purse seine with FAD $48.75 \%$, traditional seine net $48.13 \%$ and hand line $68.18 \%$. Low sustainability of fishing technologies caused by small size dominantly in catch, percentage of catch suitable length, investment, income, number of labour dan fuell used, and protected organism in catch.
\end{abstract}

Keywords: Sustainability, fishing technology, Skipjack

\section{ABSTRAK}

Ikan cakalang merupakan komoditas perikanan penting di perairan Teluk Bone. Ikan cakalang merupakan salah satu ikan target yang dieksploitasi nelayan sepanjang tahun menggunakan berbagai jenis teknologi penangkapan ikan seperti huhate (pole and line), pukat cincin (purse seine), payang (traditional seine net), pancing tangan (hand line) dan diduga ada diantara teknologi tersebut tidak berkelanjutan. Penelitian bertujuan menganalisis keberlanjutan/keramahan lingkungan teknologi penangkapan ikan cakalang di perairan Teluk Bone, selama enam bulan (Januari - Juni 2017). Data biologi hasil tangkapan, teknis alat tangkap dan sosial ekonomi usaha penangkapan huhate, pukat cincin, payang, dan pancing tangan dikumpulkan secara langsung menggunakan metode survei. Keberlanjutan/keramahan lingkungan teknologi penangkapan ikan dianalisis menggunakan 14 kriteria sesuai metode Arimoto modifikasi Mallawa. Hasil penelitian menunjukkan bahwa huhate rumpon mencapai nilai keberlanjutan $57,50 \%$, huhate tanpa rumpon $76,88 \%$, pukat cincin $51,25 \%$, pukat cincin rumpon $48,75 \%$, payang $48,13 \%$ dan pancing tangan $68,13 \%$. Rendahnya tingkat keberlanjutan teknologi penangkapan disebabkan oleh dominannya ikan ukuran kecil dan rendahnya ikan ukuran layak tangkap, nilai 
investasi, tingkat pendapatan, penggunaan tenaga kerja dan BBM dan tertangkapnya biota laut yang dilindungi.

Kata kunci: Keberlanjutan, teknologi penangkapan, ikan cakalang.

\section{PENDAHULUAN}

Penangkapan ikan cakalang (Katsuwonus pelamis) merupakan salah satu kegiatan perikanan tangkap yang menonjol di Wilayah Pengelolaan Perikanan Republik Indonesia 713 (WPP RI 713) khususnya di perairan Teluk Bone. Penangkapan ikan membuka lapangan kerja yang luas tidak hanya bagi nelayan penangkap ikan tetapi juga bagi mereka yang bergerak di bidang penanganan dan pengolahan ikan, pedagang ikan, penjual ikan, penyedia kebutuhan armada penangkapan dan lainnya. Berdasarkan analisis data statistik perikanan, Mallawa et al. (2016) melaporkan bahwa produksi tahunan, prokuksi maksimum lestari (Maximum Sustainable Yield) dan jumlah tangkapan diperbolehkan (Total Allowable Catch) ikan cakalang di perairan Teluk Bone sebesar masingmasing $6.666,20$ ton per tahun, $20.154,24$ ton per tahun, dan $16.123,37$ ton per tahun, serta upaya tahunan dan upaya optimum tahunan masing-masing sebesar 2.208 unit dan 1.422 unit setara pukat cincin, yang bermakna bahwa kegiatan penangkapan ikan cakalang di perairan tersebut masih memungkinkan untuk ditingkatkan. Nelayan perairan Teluk Bone dalam melakukan kegiatan penangkapan ikan cakalang menggunakan beberapa jenis alat penangkapan ikan dengan tingkat teknologi yang berbeda satu dengan lainnya. Alat tangkap tersebut yaitu payang (traditional seine net), pukat cincin (purse seine), jaring insang permukaan tetap (set surface gill net), jaring insang permukaan hanyut (drift surface gill net), bagan perahu (boat lift net), pancing tonda (trolling line), rawai permukaan tetap (set small surface long line), rawai tegak (vertical long line) dan pancing tangan (hand line). Pukat cincin dan huhate melakukan penangkapan ikan cakalang melalui perburuan gerombolan ikan atau menangkap di area rumpon, demikian pula dengan payang dan pancing tangan selalu menangkap di area rumpon. Adapun pancing tonda, jaring insang permukaan, bagan perahu dan rawai permukaan melakukan penangkapan ikan tidak menggunakan rumpon. Penggunaan rumpon memberikan kepastian lokasi daerah penangkapan ikan, sehingga dapat mengurangi biaya operasional khususnya bahan bakar minyak dan menurunnya ketidakberhasilan mendapatkan ikan. Namun di lain pihak pemasangan rumpon diduga menjadi penyebab utama menurunnya kualitas populasi ikan cakalang. Mallawa et al. (2017) yang melakukan kajian stok berbasis data biologi menjelaskan bahwa telah terjadi penurunan kondisi biologi populasi atau kondisi stok ikan cakalang di perairan Teluk Bone. Hal tersebut ditandai antara lain dominannya ikan cakalang berukuran kecil atau ikan muda dalam hasil tangkapan, menurunnya laju pertumbuhan populasi dan tidak optimalnya proses rekruitmen. Garbin dan Castelllo (2014) menjelaskan bahwa penangkapan ikan cakalang secara terus menerus dengan pole and line di perairan Atlantik menyebabkan menurunnya ukuran ikan dalam populasi dan menurunnya laju pertumbuhan ikan cakalang. Penurunan kondisi stok ikan cakalang di perairan Teluk Bone diduga sebagai akibat penggunaan berbagai teknologi penangkapan ikan yang tidak selektif, intensifnya penangkapan sepanjang tahun dan penggunaan alat bantu pengumpul ikan atau rumpon (Fish Aggregation Device) oleh nelayan setempat. Mallawa (2016b) melaporkan bahwa di perairan Teluk Bone ikan cakalang yang tertangkap huhate melalui perburuan memiliki ukuran relatif lebih besar dibanding ikan cakalang yang tertangkap di area rumpon.

Permasalahan teknologi penangkapan ikan cakalang yang tidak berkelanjutan atau tidak ramah lingkungan juga menjadi topik bahasan beberapa peneliti di berbagai perairan dunia. Hallier and Gartner (2008) melaporkan bahwa penggunaan rumpon hanyut (drifting fish aggregation devices) pada pukat cincin untuk kegiatan penangkapan ikan cakalang di perairan tropis Prancis menyebabkan penurunan tingkat keberlanjutan alat tangkap tersebut. Selanjutnya dijelaskan bahwa alat pengumpul ikan atau rumpon dapat menjadi perangkap ekologi bagi ikan tuna dan cakalang. Davies et al. (2014) menjelaskan bahwa penggunaan alat bantu penangkapan ikan (FADs) oleh nelayan dalam melakukan penangkapan ikan dapat meningkatkan nilai ekonomi usaha namun memberikan dampak ekologi yang cukup nyata. Wang et al. (2012) melaporkan bahwa di perairan Pasifik Barat ikan cakalang yang tertangkap pukat cincin di area alat bantu penangkapan ikan (rumpon) memiliki ukuran relatif lebih kecil. Rendahnya tingkat keberlanjutan teknologi penangkapan ikan cakalang khususnya yang menggunakan alat bantu penangkapan ikan (FADs) juga menjadi perhatian penggiat kelestarian sumber daya laut seperti WWF dan Greenpeace di mana kedua organisasi ini giat 
mengkampanyekan pelarangan penggunaan rumpon.

\section{METODE}

Penelitian ini dilakukan selama 6 (enam) bulan yaitu dari Januari-Juni 2017 di Perairan Teluk Bone, Sulawesi Selatan. Lokasi penelitian disajikan pada Gambar 1.

Bahan yang digunakan dalam penelitian ini meliputi ikan cakalang dan beberapa bahan kimia sedangkan peralatan penelitian antara lain kapal perikanan, rumpon, GPS, kamera digital, papan ukur, fish finder, current meter, salinometer komputer dan perangkat lunaknya. Bahan dan peralatan penelitian serta kegunaannya disajikan pada Tabel 1.

Penelitian ini menggunakan metode survei. Data primer utama meliputi panjang ikan (cm FL), kesegaran ikan hasil tangkapan, pengaruh teknologi penangkapan terhadap habitat, pengaruh teknologi terhadap kesehatan nelayan, pengaruh teknologi terhadap biota perairan yang dilindungi, hasil tangkapan sampingan, penggunaan BBM, penggunaan tenaga kerja menurut teknologi penangkapan ikan dikum- pulkan melalui: (1) pengukuran dan pengamatan langsung di atas kapal saat operasi penangkapan ikan dilakukan nelayan dan di tempat pendaratan ikan, dan (2) wawancara dengan nelayan, pengusaha penangkapan ikan, dan pengambil kebijakan. Adapun data primer utama berkaitan dengan nilai investasi, tingkat pendapatan usaha, aspek legal, dan kearifan lokal dan dikumpulkan melalui wawancara terstruktur dengan memakai bantuan daftar pertanyaan. Data primer pendukung meliputi posisi daerah penangkapan ikan, kedalaman perairan daerah penangkapan ikan, posisi rumpon, arah dan kecepatan arus, salinitas, suhu perairan dan lainnya dikumpulkan secara insitu saat operasi penangkapan berlangsung. Sampel gonad untuk pengamatan TKG secara morfologi dan histologi diambil saat ikan baru tertangkap atau dalam keadaan segar. Data sekunder berkaitan dengan data primer khususnya sebaran panjang ikan hasil tangkapan menurut teknologi penangkapan ikan cakalang yang menjadi kajian, juga dikumpulkan dari hasil penelitian sebelumnya melalui desk study. Jenis data primer dan data sekunder, metode pengumpulan dan sumber data disajikan pada Tabel 2.

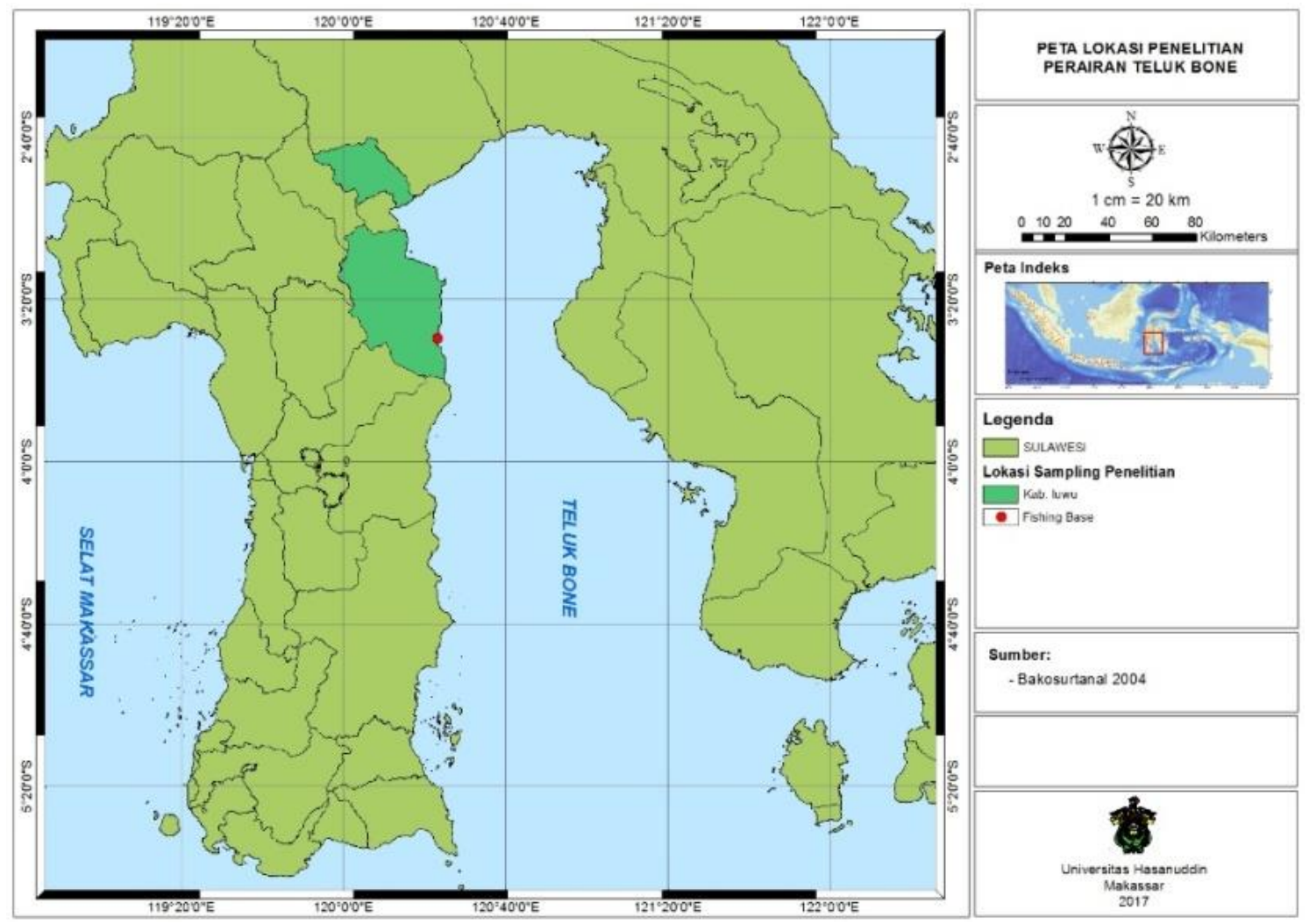

Gambar 1 Lokasi penelitian 
Tabel 1 Bahan dan peralatan penelitian serta kegunaannya

\begin{tabular}{|c|c|c|}
\hline Bahan dan Peralatan & Kegunaannya & Keterangan \\
\hline \multicolumn{3}{|l|}{ Bahan } \\
\hline Ikan cakalang & Pengukuran panjang & $\begin{array}{l}\text { Mengamati struktur } \\
\text { ukuran }\end{array}$ \\
\hline Bahan kimia & $\begin{array}{l}\text { Penyiapan bahan pengamatan } \\
\text { histology }\end{array}$ & $\begin{array}{l}\text { Menentukan ukuran } \\
\text { layak tangkap }\end{array}$ \\
\hline \multicolumn{3}{|c|}{ 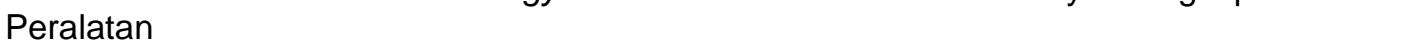 } \\
\hline $\begin{array}{l}\text { Global Positioning } \\
\text { System (GPS) }\end{array}$ & $\begin{array}{l}\text { Mengetahui posisi daerah } \\
\text { penangkapan }\end{array}$ & Data pendukung \\
\hline Current meter & Mengetahui arah dan kecepatan arus & Data pendukung \\
\hline Hand refractometer & $\begin{array}{l}\text { Pengukuran salinitas perairan lokasi } \\
\text { penangkapan ikan }\end{array}$ & Data pendukung \\
\hline Digital thermometer & $\begin{array}{l}\text { Pengukuran suhu perairan lokasi } \\
\text { penangkapan }\end{array}$ & Data pendukung \\
\hline Fish finder & $\begin{array}{l}\text { Pengukuran kedalaman perairan } \\
\text { lokasi penangkapan ikan }\end{array}$ & Data pendukung \\
\hline $\begin{array}{l}\text { Papan ukur } \\
\text { Tape recorder }\end{array}$ & Pengukuran panjang ikan & Data utama \\
\hline $\begin{array}{l}\text { Unit penangkapan ikan } \\
\text { (kapal ikan dan alat } \\
\text { penangkapan) }\end{array}$ & Tempat pengumpulan ikan contoh & $\begin{array}{l}\text { lkan sampel untuk } \\
\text { pengukuran panjang } \\
\text { dan pengambilan gonad }\end{array}$ \\
\hline Rumpon & Alat bantu penangkapan & $\begin{array}{l}\text { Lokasi penangkapan } \\
\text { ikan }\end{array}$ \\
\hline
\end{tabular}

Tabel 2 Jenis data, metode pengumpulan dan sumber data

\begin{tabular}{|l|l|l|}
\hline \multicolumn{1}{|c|}{ Jenis data } & \multicolumn{1}{|c|}{$\begin{array}{c}\text { Metode } \\
\text { pengumpulan }\end{array}$} & \multicolumn{1}{c|}{ Sumber data } \\
\hline $\begin{array}{l}\text { Primer utama : panjang ikan/struktur ukuran, } \\
\text { produksi per trip, jumlah trip per bulan, lama musim } \\
\text { penangkapan, harga jual ikan, biaya operasional, } \\
\text { biaya investasi, jumlah tenaga kerja per unit upaya, } \\
\text { by catcth, kualitas ikan, saat didaratkan, pengaruh } \\
\text { terhadap habitat dan keanekaragaman hayati, } \\
\text { dampak terhadap kesehatan dan keselamatan } \\
\text { manusia, dan sebagainya }\end{array}$ & $\begin{array}{l}\text { Field survey } \\
\text { observasi } \\
\text { pengamatan } \\
\text { lapangan) dan } \\
\text { wawancara } \\
\text { terstruktur }\end{array}$ & $\begin{array}{l}\text { Nelayan } \\
\text { penangkap ikan, } \\
\text { pemilik usaha } \\
\text { penangkapan, } \\
\text { pengambil } \\
\text { kebijakan }\end{array}$ \\
\hline $\begin{array}{l}\text { Primer pendukung : posisi daerah penangkapan, } \\
\text { kedalaman perairan, salinitas dan suhu perairan, } \\
\text { arah dan kecepatan arus }\end{array}$ & $\begin{array}{l}\text { Observasi } \\
\text { melalui } \\
\text { pengukuran } \\
\text { langsung saat } \\
\text { operasi } \\
\text { penangkapan }\end{array}$ & Insitu \\
\hline $\begin{array}{l}\text { Data sekunder : panjang ikan/struktur ukuran, } \\
\text { produksi per trip, jumlah trip per bulan, lama musim } \\
\text { penangkapan, harga jual ikan, biaya operasional, } \\
\text { biaya investasi, jumlah tenaga kerja per unit upaya, } \\
\text { by catcth, kualitas ikan saat didaratkan, pengaruh } \\
\text { terhadap habitat dan keanekaragaman hayati, } \\
\text { dampak terhadap kesehatan dan keselamatan } \\
\text { manusia, dan sebagainya }\end{array}$ & Desk study & $\begin{array}{l}\text { Laporan } \\
\text { penelitian, jurnal } \\
\text { nasional \& } \\
\text { internasional, } \\
\text { prosiding } \\
\text { nasional \& } \\
\text { internasional }\end{array}$ \\
\hline $\begin{array}{l}\text { Data sekunder: kondisi oseanografi daerah } \\
\text { penangkapan ikan cakalang, daerah potensil } \\
\text { penangkapan ikan cakalang }\end{array}$ & & $\begin{array}{l}\text { Laporan } \\
\text { penelitian, jurnal } \\
\text { nasional \& } \\
\text { internasional, } \\
\text { prosiding } \\
\text { nasional \& } \\
\text { internasional }\end{array}$ \\
\hline
\end{tabular}


Tabel 3 Analisis keberlanjutan/keramahan lingkungan teknologi penangkapan

\begin{tabular}{|c|c|c|c|}
\hline Kriteria & Sub Kriteria & Bobot & $\begin{array}{l}\text { Nilai Sub } \\
\text { Kriteria }\end{array}$ \\
\hline $\begin{array}{l}\text { Struktur ukuran ikan } \\
\text { hasil tangkapan }\end{array}$ & $\begin{array}{l}\text { Dominan ikan ukuran kecil } \\
\text { Dominan ukuran kecil sampai sedang } \\
\text { Dominan ukuran sedang sampai besar } \\
\text { Dominan ikan berukuran besar }\end{array}$ & 1,00 & $\begin{array}{l}1 \\
2 \\
3 \\
4\end{array}$ \\
\hline $\begin{array}{l}\text { Persentase ikan } \\
\text { layak tangkap }\end{array}$ & $\begin{array}{l}<10 \% \text { ikan layak tangkap } \\
10 \%-<20 \% \text { ikan layak tangkap } \\
20 \%-<30 \% \text { ikan layak tangkap } \\
\geq 30 \% \text { ikan layak tangkap }\end{array}$ & 1,00 & $\begin{array}{l}1 \\
2 \\
3 \\
4\end{array}$ \\
\hline Dampak ke habitat & $\begin{array}{l}\text { Merusak habitat pada wilayah luas } \\
\text { Merusak habitat pada wilayah sempit } \\
\text { Merusak sebagian habitat pada wilayah sempit } \\
\text { Aman bagi habitat }\end{array}$ & 0,75 & $\begin{array}{l}1 \\
2 \\
3 \\
4\end{array}$ \\
\hline $\begin{array}{l}\text { Kualitas ikan hasil } \\
\text { tangkapan }\end{array}$ & $\begin{array}{l}\text { Ikan mati dan busuk } \\
\text { Ikan mati dan cacat fisik } \\
\text { Ikan mati dan segar } \\
\text { Ikan hidup }\end{array}$ & 0,50 & $\begin{array}{l}1 \\
2 \\
3 \\
4\end{array}$ \\
\hline $\begin{array}{l}\text { Dampak teknologi ke } \\
\text { nelayan }\end{array}$ & $\begin{array}{l}\text { Dapat menyebabkan kematian } \\
\text { Dapat mengakibatkan cacat } \\
\text { Dapat mengganggu kesehatan } \\
\text { Aman bagi nelayan }\end{array}$ & 0,50 & $\begin{array}{l}1 \\
2 \\
3 \\
4\end{array}$ \\
\hline $\begin{array}{l}\text { Dampak hasil } \\
\text { tangkapan ke } \\
\text { konsumen }\end{array}$ & $\begin{array}{l}\text { Berpeluang menyebabkan kematian } \\
\text { Dapat menyebabkan gangguan kesehatan } \\
\text { Relatif aman bagi konsumen } \\
\text { Aman bagi konsumen }\end{array}$ & 0,50 & $\begin{array}{l}1 \\
2 \\
3 \\
4\end{array}$ \\
\hline $\begin{array}{l}\text { Hasil tangkapan } \\
\text { sampingan (by } \\
\text { catch) }\end{array}$ & $\begin{array}{l}\text { Beberapa spesies tidak laku terjual } \\
\text { Beberapa spesies dan ada laku terjual } \\
\text { By catch }<3 \text { spesies dan laku terjual } \\
\text { By catch }<3 \text { spesies dan bernilai tinggi }\end{array}$ & 0,50 & $\begin{array}{l}1 \\
2 \\
3 \\
4\end{array}$ \\
\hline $\begin{array}{l}\text { Dampak teknologi ke } \\
\text { biodiversity }\end{array}$ & $\begin{array}{l}\text { Sering menangkap ikan dilindungi } \\
\text { Beberapa kali menangkap ikan dilindungi } \\
\text { Pernah menangkap ikan dilindungi } \\
\text { Tidak pernah menangkap ikan dilindungi }\end{array}$ & 0,75 & $\begin{array}{l}1 \\
2 \\
3 \\
4\end{array}$ \\
\hline $\begin{array}{l}\text { Penggunaan bahan } \\
\text { bakar minyak }\end{array}$ & $\begin{array}{l}\text { Penggunaan BBM > Rp. } 2 \text { juta per trip } \\
\text { Penggunaan BBM Rp. } 1-2 \text { juta per trip } \\
\text { Penggunaan BBM Rp. } 0,5-<1 \text { juta per trip } \\
\text { Penggunaan BBM }<\text { Rp. } 0,5 \text { juta per trip }\end{array}$ & 0,75 & $\begin{array}{l}1 \\
2 \\
3 \\
4\end{array}$ \\
\hline $\begin{array}{l}\text { Nilai biaya investasi } \\
\text { usaha }\end{array}$ & $\begin{array}{l}\text { Nilai investasi > Rp. } 300 \text { juta per unit } \\
\text { Nilai investasi Rp } 200-300 \text { juta per unit } \\
\text { Nilai investasi Rp. } 100-<200 \text { juta per unit } \\
\text { Nilai investasi }<\text { Rp. } 100 \text { juta per unit }\end{array}$ & 0,75 & $\begin{array}{l}1 \\
2 \\
3 \\
4\end{array}$ \\
\hline $\begin{array}{l}\text { Penyerapan tenaga } \\
\text { kerja }\end{array}$ & $\begin{array}{l}\text { Menyerap }<5 \text { tenaga kerja } \\
\text { Menyerap } 5-<10 \text { tenaga kerja } \\
\text { Menyerap } 10-<15 \text { tenaga kerja } \\
\text { Menyerap } \geq 15 \text { tenaga kerja }\end{array}$ & 1,00 & $\begin{array}{l}1 \\
2 \\
3 \\
4\end{array}$ \\
\hline Keuntungan usaha & $\begin{array}{l}\text { Keuntungan }<\text { Rp. } 100 \text { juta per tahun } \\
\text { Keuntungan Rp. } 100-<250 \text { juta per tahun } \\
\text { Keuntungan Rp. } 250-<500 \text { juta per tahun } \\
\text { Keuntungan } \geq \text { Rp. } 500 \text { juta per tahun } \\
\end{array}$ & 1,00 & $\begin{array}{l}1 \\
2 \\
3 \\
4\end{array}$ \\
\hline Legalitas teknologi & $\begin{array}{l}\text { Bertentangan dengan }>\text { dua peraturan } \\
\text { Bertentangan dengan dua peraturan } \\
\text { Bertentangan dengan satu peraturan } \\
\text { Tidak bertentangam aturan }\end{array}$ & 0,50 & $\begin{array}{l}1 \\
2 \\
3 \\
4\end{array}$ \\
\hline $\begin{array}{l}\text { Kaitan teknologi dan } \\
\text { adat istiadat dan } \\
\text { kearifan lokal }\end{array}$ & $\begin{array}{l}\text { Sangat bertentangan adat istiadat dan kearifan lokal } \\
\text { Bertentangan adat istiadat dan kearifan lokal } \\
\text { Sedikit bertentangan adat istiadat dan kearifan lokal } \\
\text { Tidak bertentangan adat istiadat dan kearifan lokal }\end{array}$ & 0,50 & $\begin{array}{l}1 \\
2 \\
3 \\
4\end{array}$ \\
\hline
\end{tabular}


Keterangan:

Tingkat keberlanjutan atau keramahan lingkungan dihitung dengan persamaan :

Keramahan Lingkungan $=\{($ bobot $x$ nilai perolehan $) /$ nilai penuh $\}$ $100 \%$

Kategori keberlanjutan/keramahan lingkungan teknologi penangkapan ikan yaitu :

Nilai perolehan $86-100 \%$, Tinggi atau sangat ramah lingkungan

Nilai perolehan 66 - 85\%, Sedang atau ramah lingkungan

Nilai perolehan $50-65 \%$, Rendah atau kurang ramah lingkungan

Nilai perolehan $<50 \%$, Sangat rendah atau tidak ramah lingkungan

Analisis keberlanjutan teknologi penangkapan ikan cakalang menggunakan 14 kriteria yaitu struktur ukuran ikan yang tertangkap, persentase ikan layak tangkap, dampak teknologi terhadap habitat, kualitas ikan hasil tangkapan, dampak teknologi terhadap nelayan, dampak teknologi terhadap keanekaragaman hayati, dampak hasil tangkapan terhadap konsumen, penggunaan bahan bakar minyak, nilai investasi, penyerapan tenaga kerja, jumlah keuntungan, legalitas teknologi, dan teknologi kaitannya dengan adat istiadat dan kearifan lokal. Struktur ukuran ikan cakalang hasil tangkapan nelayan menurut teknologi penangkapan dianalisis secara deskriptif untuk mengetahui ukuran ikan terkecil, terbesar dan dominan berdasarkan teknologi penangkapan ikan cakalang. Persentase ikan cakalang layak tangkap dalam hasil tangkapan nelayan masing-masing teknologi penangkapan ikan cakalang dihitung menggunakan metode Mallawa (2013) sebagai berikut :

Ikan Layak Tangkap (\%) = ( $($ ikan layak tangkap/ $\Sigma$ Hasil Tangkapan) x 100\%

Ikan layak tangkap (\%) dalam hasil tangkapan nelayan masing-masing teknologi penangkapan ikan cakalang dihitung menurut metode yang dikemukakan Mallawa (2013), Ikan layak tangkap adalah ukuran ikan yang sudah pernah melakukan pemijahan.

Ikan layak tangkap didasarkan pada Tingkat Kematangan Gonad (TKG) secara morfologi adalah pada fase TKG 5 atau secara histologi pada fase vitelligenetik (late vitelligenetic). Analisis tingkat kematangan gonad menggunakan metode Ashida et al. (2009) dan Itano (2011). Untuk membedakan tingkat keberlanjutan antar teknologi penangkapan ikan, setiap kriteria diberi bobot. Dimana nilai bobot total adalah 10 dan dibagi menjadi empat sub kriteria dengan nilai 14 sehingga nilai penuh adalah 40 . Selanjutnya ke 14 kriteria disatukan dalam "Tabel Analisis Keberlanjutan/Keramahan Lingkungan Teknologi Penangkapan (Arimoto modifikasi Mallawa 2013) seperti disajikan pada Tabel 3.

\section{HASIL PENELITIAN}

\section{Struktur ukuran dan persentase ikan layak tangkap.}

Hasil pengamatan terhadap hasil tangkapan semua teknologi penangkapan ikan cakalang (Gambar 2) di perairan Teluk Bone didapatkan bahwa ukuran ikan cakalang terkecil, terbesar dan ukuran dominan dan persentase ikan layak tangkap dalam hasil tangkapan menurut jenis teknologi penangkapan ikan yang dipergunakan nelayan seperti disajikan pada Gambar 3 dan 4.

Gambar 3 dan 4 menjelaskan bahwa ikan yang tertangkap pada daerah rumpon atau teknologi penangkapan yang dikombinasikan dengan rumpon, hasil tangkapannya relatif lebih kecil dibanding hasil tangkapan di luar rumpon. Demikian pula ikan layak tangkap persentasenya lebih kecil pada alat alat tangkap yang dioperasikan di rumpon kecuali pancing tangan.

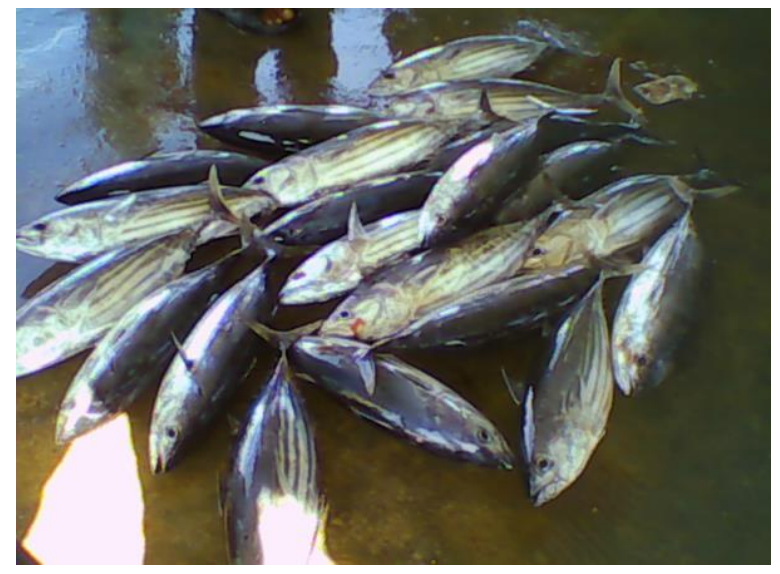

Gambar 2 Ikan Cakalang hasil tangkapan nelayan perairan Teluk Bone 


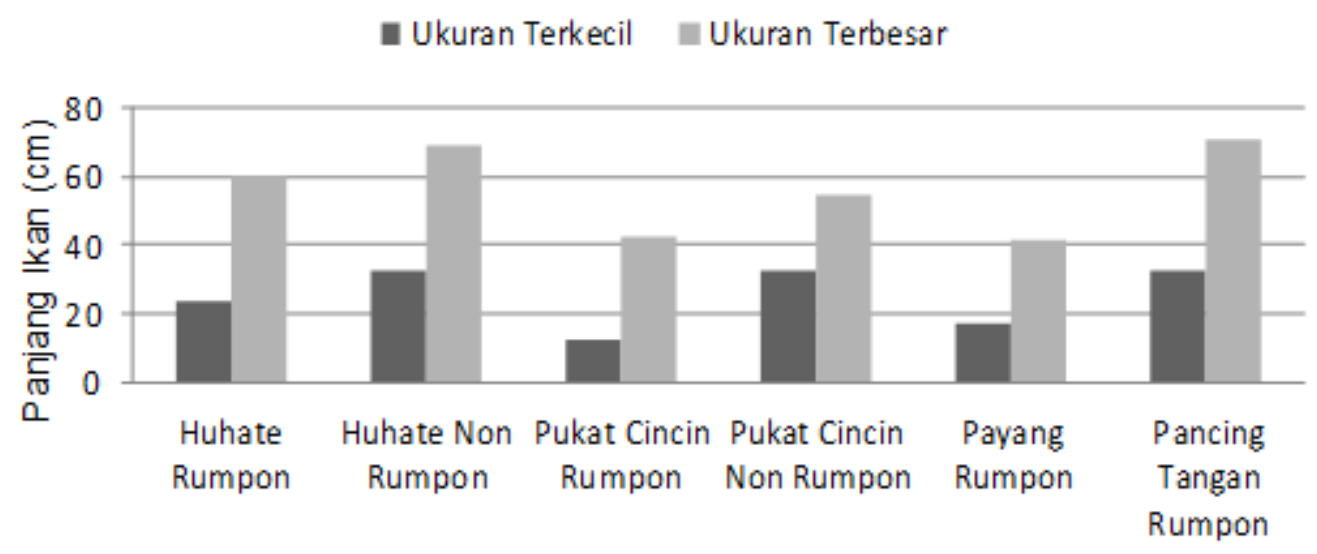

\author{
Ukuran Dominan (cm) \\ IR: $32,5-42,5$. HIR : 40,5-55,5. PCR : 23,5- $32,5$. \\ PCIR : $32,5-37,5$. SNR: $17,5-27,5$. HR : $40,5-55,5$.
}

Gambar 3 Ukuran terkecil, terbesar dan ukuran dominan ikan cakalang hasil tangkapan berdasarkan teknologi penangkapan yang digunakan di perairan Teluk Bone.

- \% layak tangkap

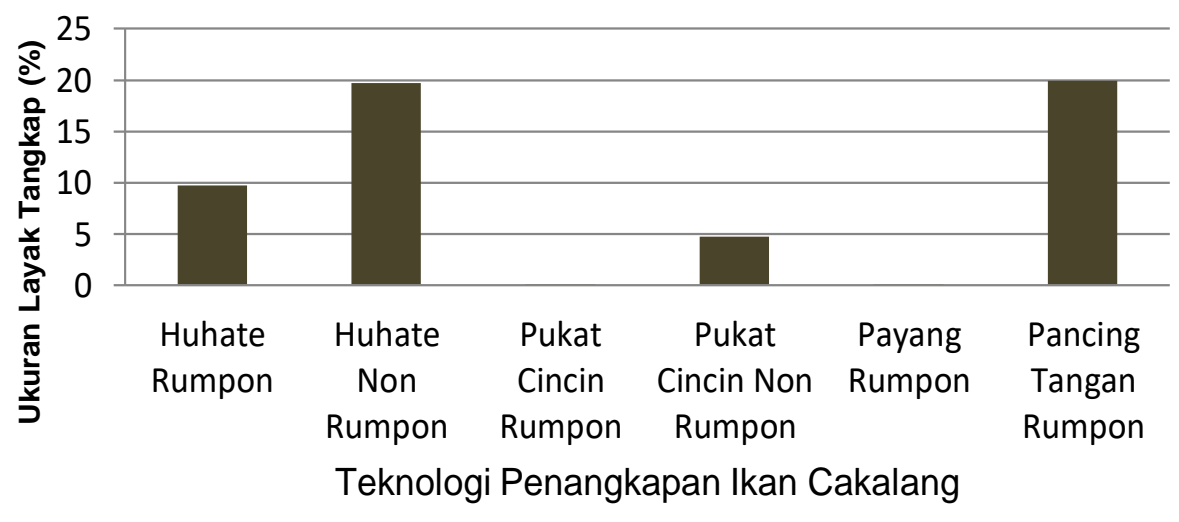

Gambar 4 Persentase ukuran layak tangkap berdasarkan teknologi penangkapan ikan cakalang yang digunakan di perairan Teluk Bone

Hasil analisis deskriptif dampak teknologi penangkapan ikan terhadap habitat, keanekaragaman hayati dan ke manusia, hasil tangkapan sampingan (by catch), kualitas hasil tangkapan dan dampak hasil tangkapan ke konsumen masing-masing teknologi penangkapan ikan cakalang di perairan Teluk Bone disajikan pada Tabel 4.

Tabel 4 memperlihatkan bahwa teknologi penangkapan ikan yang menggunakan alat bantu penangkapan ikan dapat menyebabkan kerusakan habitat dalam wilayah sempit, sebatas pergeseran pemberat rumpon dan terbuangnya bahan rumpon yang tidak dapat terurai ke dalam perairan. Pada prakteknya pada pukat cincin dan payang sebelum dilakukan pe- lingkaran rumpon, seorang nelayan harus menyelam untuk mengecek apakah sudah banyak ikan di area rumpon dan hal ini dapat membahayakan kesehatan bagi nelayan dan menyebabkan kematian. Dampak lain penggunaan rumpon pada pukat cincin dan payang adalah sering tertangkapnya biota laut yang dilindungi seperti penyu, lumba-lumba dan ikan hiu

Hasil pengamatan dan perhitungan penggunaan bahan bakar minyak, biaya investasi, keuntungan, penyerapan tenaga kerja, aspek legalitas, dan kaitan dengan adat istiadat dan kearifan lokal masing-masing teknologi penangkapan ikan cakalang di perairan Teluk Bone disajikan pada Tabel 5. 
Tabel 4 Dampak teknologi ke lingkungan, biota, dan manusia

\begin{tabular}{|c|c|c|c|c|c|c|}
\hline \multirow[t]{2}{*}{ Uraian } & \multicolumn{6}{|c|}{ Teknologi Penangkapan Ikan } \\
\hline & $\mathrm{HR}$ & HTR & PCR & PCTR & SNR & HLR \\
\hline $\begin{array}{l}\text { Kerusakan } \\
\text { habitat }\end{array}$ & $\begin{array}{l}\text { Sebagian } \\
\text { dan } \\
\text { sempit }\end{array}$ & $\begin{array}{l}\text { Aman } \\
\text { bagi } \\
\text { habitat }\end{array}$ & $\begin{array}{l}\text { Sebagian } \\
\text { dan sempit }\end{array}$ & $\begin{array}{l}\text { Aman bagi } \\
\text { habitat }\end{array}$ & $\begin{array}{l}\text { Sebagian dan } \\
\text { sempit }\end{array}$ & $\begin{array}{l}\text { Aman bagi } \\
\text { habitat }\end{array}$ \\
\hline Biota dilindungi & Aman & Aman & $\begin{array}{l}\text { Sering } \\
\text { tertangkap }\end{array}$ & $\begin{array}{l}\text { Pernah } \\
\text { menangkap }\end{array}$ & $\begin{array}{l}\text { Sering } \\
\text { tertangkap }\end{array}$ & $\begin{array}{l}\text { Pernah } \\
\text { menangkap }\end{array}$ \\
\hline Ke nelayan & Aman & Aman & $\begin{array}{l}\text { Dapat } \\
\text { mengganggu } \\
\text { kesehatan }\end{array}$ & Aman & $\begin{array}{l}\text { Dapat } \\
\text { menyebabkan } \\
\text { kematian }\end{array}$ & $\begin{array}{l}\text { Aman bagi } \\
\text { nelayan }\end{array}$ \\
\hline By catch & $\begin{array}{l}<3 \text { sp } \\
\text { dan } \\
\text { bernilai } \\
\text { tinggi }\end{array}$ & $\begin{array}{l}<3 \text { sp } \\
\text { dan } \\
\text { bernilai } \\
\text { tinggi }\end{array}$ & $\begin{array}{l}\text { Beberapa } \\
\text { spesies dan } \\
\text { ada laku } \\
\text { terjual }\end{array}$ & $\begin{array}{l}\text { Beberapa } \\
\text { spesies } \\
\text { dan ada } \\
\text { laku dijual }\end{array}$ & $\begin{array}{l}\text { Beberapa } \\
\text { hasil } \\
\text { tangkapan tdk } \\
\text { laku terjual }\end{array}$ & $\begin{array}{l}<2 \text { spesis } \\
\text { bernilai } \\
\text { tinggi }\end{array}$ \\
\hline $\begin{array}{l}\text { Kualitas ikan } \\
\text { hasil tangkapan }\end{array}$ & $\begin{array}{l}\text { Mati, } \\
\text { segar }\end{array}$ & $\begin{array}{l}\text { Mati, } \\
\text { segar }\end{array}$ & $\begin{array}{l}\text { Mati, } \\
\text { Segar }\end{array}$ & $\begin{array}{l}\text { Mati, } \\
\text { Segar }\end{array}$ & $\begin{array}{l}\text { Mati, } \\
\text { Segar }\end{array}$ & $\begin{array}{l}\text { Mati, } \\
\text { Segar }\end{array}$ \\
\hline $\begin{array}{l}\text { Hasil tangkapan } \\
\text { ke manusia }\end{array}$ & $\begin{array}{l}\text { Relatif } \\
\text { aman }\end{array}$ & $\begin{array}{l}\text { Relatif } \\
\text { aman }\end{array}$ & $\begin{array}{l}\text { Relatif } \\
\text { aman }\end{array}$ & $\begin{array}{l}\text { Relatif } \\
\text { aman }\end{array}$ & $\begin{array}{l}\text { Dapat } \\
\text { mengganggu } \\
\text { kesehatan }\end{array}$ & $\begin{array}{l}\text { Relatif } \\
\text { aman }\end{array}$ \\
\hline
\end{tabular}

Keterangan $\mathrm{HR}=$ huhate rumpon, $\mathrm{HTR}=$ huhate tanpa rumpon, $\mathrm{PCR}=$ pukat cincin rumpon, PCTR = pukat cincin tanpa rumpon, SNR = payang rumpon, $\mathrm{HLR}$ = pancing tangan rumpon.

Tabel 5 Aspek ekonomi, sosial dan hukum teknologi peangkapan ikan

\begin{tabular}{|c|c|c|c|c|c|c|}
\hline \multirow[t]{2}{*}{ Uraian } & \multicolumn{6}{|c|}{ Teknologi Penangkapan Ikan } \\
\hline & $\mathrm{HR}$ & HTR & PCR & PCTR & SNR & HLR \\
\hline $\begin{array}{l}\text { Penggunaan BBM (Rp juta) } \\
\text { per trip }\end{array}$ & $2,0-2,5$ & & $0,5-1,0$ & $0,5-1,0$ & $0,1-0,2$ & $0,1-0,3$ \\
\hline Nilai investasi (Rp juta) & $\begin{array}{l}750- \\
1.000\end{array}$ & $\begin{array}{l}750- \\
1.000\end{array}$ & $\begin{array}{l}300- \\
500\end{array}$ & $\begin{array}{l}300- \\
500\end{array}$ & $<100$ & $<100$ \\
\hline $\begin{array}{l}\text { Penyerapan tenaga kerja } \\
\text { (orang) }\end{array}$ & $10-15$ & $10-14$ & $5-9$ & $5-9$ & $2-3$ & $1-2$ \\
\hline Keuntungan (Rp juta) & $>500$ & $>500$ & $\begin{array}{l}200- \\
490\end{array}$ & $\begin{array}{l}200- \\
490\end{array}$ & $<100$ & $<100$ \\
\hline $\begin{array}{l}\text { Legalitas (bertentangan } \\
\text { peraturan) }\end{array}$ & $\begin{array}{l}\text { Satu } \\
\text { aturan }\end{array}$ & $\begin{array}{l}\text { Tidak } \\
\text { ada }\end{array}$ & $\begin{array}{l}\text { Dua } \\
\text { aturan }\end{array}$ & $\begin{array}{l}\text { Satu } \\
\text { aturan }\end{array}$ & $\begin{array}{l}\text { tiga } \\
\text { aturan }\end{array}$ & $\begin{array}{l}\text { Satu } \\
\text { aturan }\end{array}$ \\
\hline Bertentangan adat istiadat & Tidak & Tidak & Tidak & Tidak & Tidak & Tidak \\
\hline
\end{tabular}

dan kearifan lokal

Keterangan: $\mathrm{HR}=$ huhate rumpon, $\mathrm{HTR}=$ huhate tanpa rumpon, $\mathrm{PCR}=$ pukat cincin rumpon, PCTR= pukat cincin tanpa rumpon, SNR = payang rumpon, $H L R=$ pancing tangan rumpon

Tabel 5 memperlihatkan bahwa aspek negatif huhate dan pukat cincin adalah tingginya nilai investasi yang diperlukan nelayan untuk memiliki unit penangkapan dan biaya operasional untuk menjalankan usaha. Dari segi sosial kedua alat tangkap ini memiliki keunggulan karena dapat menyerap banyak tenaga kerja. Dari segi peraturan dan perundang-undangan, huhate dan pancing tangan tidak bertentangan dengan satu aturan pun. Payang termasuk alat tangkap yang dilarang dan pukat cincin bermasalah dalam zona pengoperasiannya dan seringnya menangkap biota laut yang dilindungi.

Data dan informasi (nilai kriteria berdasarkan sub kriteria capaian) yang tersaji pada Gambar 3 dan 4 dan Tabel 4-5 di atas selanjut- nya digunakan untuk menganalisis keberlanjutan atau keramahan lingkungan masing-masing teknologi penangkapan ikan cakalang di perairan Teluk Bone. Analisis dan hasil analisis tingkat keberlanjutan atau keramahan lingkungan teknologi huhate, huhate plus rumpon, pukat cincin, pukat cincin plus rumpon, payang dan pancing tangan disajikan pada Tabel 6-11.

Berdasarkan hasil analisis (Tabel 6 - 11) dapat dijelaskan bahwa di perairan Teluk Bone, huhate (pole and line) yang di dalam metode pengoperasiannya melakukan perburuan gerombolan ikan, memiliki tingkat keberlanjutan yang tinggi atau ramah lingkungan. Namun tingkat keberlanjutannya akan menurun apabila melakukan penangkapan ikan cakalang di area 
rumpon. Hal yang sama terjadi pada pukat cincin (purse seiene) di mana pukat cincin yang menangkap ikan cakalang melalui perburuan gerombolan memiliki tingkat keberlanjutan sedang atau cukup ramah lingkungan dan menjadi tidak berkelanjutan atau tidak ramah lingkungan apabila melakukan penangkapan ikan di area rumpon. Payang (traditional seine net) berdasarkan hasil analisis tidak berkelanjutan atau tidak ramah lingkungan, di mana alat tangkap ini selain memiliki penampilan biologi, teknis dan sosial ekonomi yang rendah juga termasuk alat tangkap yang dilarang pengoperasiannya oleh Kementerian Kelautan dan Perikanan Republik Indonesia.

Tabel 6 Analisis keberlanjutan/keramahan lingkungan huhate plus rumpon

\begin{tabular}{lccc}
\hline Kategori/Sub Kategori & Bobot & Nilai & Bobotx Nilai \\
\hline Struktur ukuran ikan cakalang tertangkap & 1,00 & 3 & 3,00 \\
Persentase ikan layak tangkap & 1,00 & 1 & 1,00 \\
Dampak terhadap habitat & 0,75 & 3 & 2,25 \\
Kualitas hasil tangkapan & 0,50 & 3 & 1,50 \\
Dampak teknologi terhadap nelayan & 0,50 & 4 & 0,50 \\
Dampak hasil tangkapan ke konsumen & 0,50 & 3 & 1,50 \\
Hasil tangkapan sampingan (by catch) & 0,75 & 3 & 2,25 \\
Dampak terhadap keanekaragaman hayati & 0,75 & 4 & 3,00 \\
Penggunaan bahan bakar minyak & 0,75 & 1 & 0,75 \\
Nilai biaya investasi usaha & 1,00 & 1 & 1,00 \\
Penyerapan tenaga kerja & 1,00 & 3 & 3,00 \\
Keuntungan unit usaha & 0,50 & 4 & 2,00 \\
Legalitas teknologi penangkapan ikan & 0,50 & 3 & 1,50 \\
Adat istiadat dan kearifan lokal & 0,50 & 4 & 2,00 \\
\hline \multicolumn{2}{c}{ Jumlah nilai perolehan } & & 23,00 \\
\hline \multicolumn{2}{c}{ Persentase keberlanjutan/keramahan lingkungan } & Cukup Ramah Lingkungan \\
\hline \multicolumn{2}{c}{ Kategori keberlanjutan/keramahan lingkungan } \\
\hline
\end{tabular}

Tabel 7 Analisis keberlanjutan/keramahan lingkungan huhate

\begin{tabular}{lccc}
\hline Kriteria & Bobot & Nilai & Bobot x Nilai \\
\hline Struktur ukuran ikan cakalang tertangkap & 1,00 & 3 & 3,00 \\
Persentase ikan layak tangkap & 1,00 & 3 & 3,00 \\
Dampak terhadap habitat & 0,75 & 4 & 3,00 \\
Kualitas hasil tangkapan & 0,50 & 3 & 1,50 \\
Dampak teknologi terhadap nelayan & 0,50 & 4 & 2,00 \\
Dampak hasil tangkapan ke konsumen & 0,50 & 3 & 1,50 \\
Hasil tangkapan sampingan (by catch) & 0,75 & 4 & 3,00 \\
Dampak terhadap keanekaragaman hayati & 0,75 & 4 & 3,00 \\
Penggunaan bahan bakar minyak & 0,75 & 1 & 0,75 \\
Nilai biaya investasi usaha & 1,00 & 1 & 1,00 \\
Penyerapan tenaga kerja & 1,00 & 3 & 3,00 \\
Keuntungan unit usaha & 0,50 & 4 & 2,00 \\
Legalitas teknologi penangkapan ikan & 0,50 & 4 & 2,00 \\
Adat istiadat dan kearifan lokal & 0,50 & 4 & 2,00 \\
\hline \multicolumn{2}{c}{ Jumlah nilai perolehan } & & 30,75 \\
\hline \multicolumn{2}{c}{ Persentase keberlanjutan/keramahan lingkungan } & Ramah Lingkungan \\
\hline \multicolumn{2}{c}{ Kategori keberlanjutan/keramahan lingkungan } \\
\hline
\end{tabular}


Tabel 8 Analisis keberlanjutan/keramahan lingkungan pukat cincin

\begin{tabular}{lccc}
\hline \multicolumn{1}{c}{ Kategori/Sub Kategori } & Bobot & Nilai & Bobot x Nilai \\
\hline Struktur ukuran ikan cakalang tertangkap & 1,00 & 2 & 2,00 \\
Persentase ikan layak tangkap & 1,00 & 1 & 1,00 \\
Dampak terhadap habitat & 0,75 & 4 & 3,00 \\
Kualitas hasil tangkapan & 0,50 & 3 & 1,50 \\
Dampak teknologi terhadap nelayan & 0,50 & 3 & 1,50 \\
Dampak hasil tangkapan ke konsumen & 0,50 & 3 & 1,50 \\
Hasil tangkapan sampingan (by catch) & 0,75 & 2 & 1,50 \\
Dampak terhadap keanekaragaman hayati & 0,75 & 3 & 2,25 \\
Penggunaan bahan bakar minyak & 0,75 & 3 & 2,25 \\
Nilai biaya investasi usaha & 1,00 & 1 & 1,00 \\
Penyerapan tenaga kerja & 1,00 & 2 & 2,00 \\
Keuntungan unit usaha & 0,50 & 3 & 1,50 \\
Legalitas teknologi penangkapan ikan & 0,50 & 3 & 1,50 \\
Adat istiadat dan kearifan lokal & 0,50 & 4 & 2,00 \\
\hline Jumlah nilai perolehan & & & 20,50 \\
\hline Persentase keberlanjutan/keramahan lingkungan & & & Cukup ramah lingkungan \\
\hline Kategori kebelanjutan/keramahan lingkungan & & &
\end{tabular}

Tabel 9 Analisis keberlanjutan/keramahan lingkungan pukat cincin rumpon

\begin{tabular}{lccc}
\hline \multicolumn{1}{c}{ Kategori/Sub Kategori } & Bobot & Nilai & Bobot x Nilai \\
\hline Struktur ukuran ikan cakalang tertangkap & 1,00 & 1 & 1,00 \\
Persentase ikan layak tangkap & 1,00 & 1 & 1,00 \\
Dampak terhadap habitat & 0,75 & 2 & 1,50 \\
Kualitas hasil tangkapan & 0,50 & 3 & 1,50 \\
Dampak teknologi terhadap nelayan & 0,50 & 2 & 1,00 \\
Dampak hasil tangkapan ke konsumen & 0,50 & 3 & 1,50 \\
Hasil tangkapan sampingan (by catch) & 0,75 & 1 & 0,75 \\
Dampak terhadap keanekaragaman hayati & 0,75 & 2 & 1,50 \\
Penggunaan bahan bakar minyak & 0,75 & 3 & 2,25 \\
Nilai biaya investasi usaha & 1,00 & 1 & 1,00 \\
Penyerapan tenaga kerja & 1,00 & 2 & 2,00 \\
Keuntungan unit usaha & 0,50 & 2 & 1,50 \\
Legalitas teknologi penangkapan ikan & 0,50 & 2 & 1,00 \\
Adat istiadat dan kearifan lokal & 0,50 & 4 & 2,00 \\
\hline Nilai perolehan & & & 19,50 \\
\hline Persentase keberlanjutan/keramahan lingkungan & & & Tidak ramah lingkungan
\end{tabular}

Tabel 10 Analisis keberlanjutan/keramahan lingkungan pancing tangan

\begin{tabular}{lccc}
\multicolumn{1}{c}{ Kategori/Sub Kategori } & Bobot & Nilai & Bobot x Nilai \\
\hline Struktur ukuran ikan cakalang tertangkap & 1,00 & 3 & 3,00 \\
Persentase ikan layak tangkap & 1,00 & 2 & 2,00 \\
Dampak terhadap habitat & 0,75 & 4 & 3,00 \\
Kualitas hasil tangkapan & 0,50 & 3 & 1,50 \\
Dampak teknologi terhadap nelayan & 0,50 & 4 & 2,00 \\
Dampak hasil tangkapan ke konsumen & 0,50 & 3 & 1,50 \\
Hasil tangkapan sampingan (by catch) & 0,75 & 4 & 3,00 \\
Dampak terhadap keanekaragaman hayati & 0,75 & 3 & 2,25 \\
Penggunaan bahan bakar minyak & 0,75 & 4 & 3,00 \\
Nilai biaya investasi usaha & 1,00 & 4 & 4,00 \\
Penyerapan tenaga kerja & 1,00 & 1 & 1,00 \\
Keuntungan unit usaha & 0,50 & 1 & 0,50 \\
Legalitas teknologi penangkapan ikan & 0,50 & 3 & 1,50 \\
Adat istiadat dan kearifan lokal & 0,50 & 4 & 2,00 \\
\hline Nilai perolehan & & & 27,25 \\
\hline Persentase keberlanjutan/keramahan lingkungan & & & Ramah Lingkungan \\
\hline Kategori keberlanjutan/keramahan lingkungan & & & \\
\hline
\end{tabular}


Tabel 11 Analisis Keberlanjutan/Keramahan Lingkungan Payang

\begin{tabular}{lccl}
\hline \multicolumn{1}{c}{ Kategori/Sub Kategori } & Bobot & Nilai & Bobot x Nilai \\
\hline Struktur ukuran ikan cakalang tertangkap & 1,00 & 1 & 1,00 \\
Persentase ikan layak tangkap & 1,00 & 1 & 1,00 \\
Dampak terhadap habitat & 0,75 & 3 & 2,25 \\
Kualitas hasil tangkapan & 0,50 & 3 & 1,50 \\
Dampak teknologi terhadap nelayan & 0,50 & 1 & 0,50 \\
Dampak hasil tangkapan ke konsumen & 0,50 & 1 & 0,50 \\
Hasil tangkapan sampingan (by catch) & 0,75 & 1 & 0,75 \\
Dampak terhadap keanekaragaman hayati & 0,75 & 1 & 0,75 \\
Penggunaan bahan bakar minyak & 0,75 & 4 & 3,00 \\
Nilai biaya investasi usaha & 1,00 & 4 & 4,00 \\
Penyerapan tenaga kerja & 1,00 & & 1,00 \\
Keuntungan unit usaha & 0,50 & 1 & 0,50 \\
Legalitas teknologi penangkapan ikan & 0,50 & 1 & 0,50 \\
Adat istiadat dan kearifan lokal & 0,50 & 4 & 2,00 \\
\hline Nilai Perolehan & & 19,25 \\
\hline Persentase Keberlanjutan/Keramahan Lingkungan & & $48,13 \%$ \\
\hline Kategori Keeberlanjutan/Keramahan Lingkungan \\
\hline
\end{tabular}

\section{PEMBAHASAN}

Salah satu hal yang menyebabkan menurunnya tingkat keberlanjutan atau keramahan lingkungan teknologi penangkapan ikan cakalang di perairan Teluk Bone adalah dominannya ikan berukuran kecil dalam hasil tangkapan sebagai akibat penggunaan rumpon. Mallawa et al. (2012) menguraikan bahwa struktur ukuran ikan cakalang tangkapan nelayan bervariasi menurut musim, daerah dan teknologi penangkapan dan didominasi oleh ikan berukuran kecil. Mallawa et al. (2017) menjelaskan bahwa kondisi stok ikan cakalang di perairan Teluk Bone mengalami penurunan yang ditandai dominannya ikan berukuran kecil dalam hasil tangkapan nelayan. Hal yang sama dikemukakan Alamsyah et al. (2014) bahwa ikan cakalang yang tertangkap pole and line di perairan Teluk Bone pada area rumpon dan luar rumpon memiliki perbedaan ukuran namun keduanya didominasi oleh ikan ukuran kecil yang belum layak tangkap. Mallawa (2016b) melaporkan bahwa kisaran panjang dan panjang rata-rata ikan cakalang yang tertangkap huhate di perairan Teluk Bone pada bulan Januari-Juni masing-masing adalah 26,0-40,2 cm dan 34,1 $\mathrm{cm}$ pada area rumpon, dan $49,3 \mathrm{~cm}-67,3 \mathrm{~cm}$ dan $55,9 \mathrm{~cm}$ pada area di luar rumpon. Selanjutnya Mallawa (2016a), bahwa persentase ikan cakalang layak tangkap di perairan Teluk Bone sangat rendah pada semua jenis teknologi penangkapan ikan. Jamal et al. (2014) melaporkan bahwa ukuran ikan kecil yang tertangkap oleh pole and line dan belum layak tangkap di perairan Teluk Bone dijumpai pada bulan Januari sampai Maret untuk Zona Utara, bulan Januari di Zona Tengah dan bulan Januari sampai Februari di Zona Selatan. Fenomena tertangkapnya ikan cakalang berukuran kecil pada area rumpon juga terjadi di perairan WPP RI 713 lainnya. Kondisi ini didukung hasil penelitian dari dari Mallawa et al. (2014b) yang menyatakan bahwa struktur ikan cakalang yang tertangkap di perairan laut Flores berbeda menurut daerah penangkapan dan teknologi penangkapan di mana ikan cakalang tersebut tertangkap. Ikan cakalang yang tertangkap di area rumpon berukuran lebih kecil dan belum masuk kategori ikan layak tangkap. Mallawa (2017) menyatakan pula bahwa ikan cakalang yang tertangkap pukat cincin di perairan Laut Flores memiliki kisaran panjang 19,5-52,5 cm, panjang rata-rata $32,5 \mathrm{~cm}$ dan panjang dominan $31,5-34,5 \mathrm{~cm}$ pada area rumpon dan kisaran panjang 26,6-63,5 cm, pan-jang ratarata $36,5 \mathrm{~cm}$ dan panjang dominan $34,5-40,0$ $\mathrm{cm}$ pada area di luar rumpon dan mayoritas tidak layak tangkap. Wang et al. (2012) menjelaskan bahwa terdapat perbedaan struktur ukuran gerombolan ikan cakalang yang berada di area alat bantu penangkapan ikan (FADs) dan gerombolan ikan di luar area rumpon di mana gerombolan ikan di luar rumpon terbentuk berdasarkan ukuran ikan, sedangkan gerombolan ikan di rumpon terbentuk tidak berdasarkan ukuran. Peningkatan penggunaan rumpon juga dapat menyebabkan terjadinya penurunan produksi alat tangkap yang menangkap di luar area rumpon. Penurunan produksi dapat mempengaruhi tingkat pendapatan unit usaha. Fonteneau (2015) melaporkan terjadinya penurunan produktivitas pukat cincin yang menangkap di luar area rumpon yang diduga diakibatkan karena keberadaan alat bantu pengumpul ikan (FADs) dalam jumlah banyak di Samudera Atlantic dan Samudera Hindia. Prayitno et al. (2017) menjelaskan 
bahwa ikan cakalang yang tertangkap di sekitar rumpon laut dalam perairan Pacitan Samudera Hindia memiliki panjang cagak rata-rata $43 \mathrm{~cm}$ pada pukat cincin dan $62 \mathrm{~cm}$ pada pancing ulur dengan tingkat kematangan gonad masingmasing I - III dan III.

Tertangkapnya ikan cakalang berukuran kecil di area rumpon disebabkan oleh dua hal yaitu: pertama, ikan cakalang terutama yang berukuran kecil mempunyai kebiasaan berkumpul dan merasa nyaman pada benda-benda terapung di tengah laut dan berusaha mendapatkan makanan di area rumpon (Govinden et al. 2012); kedua, rumpon umumnya dipasang di perairan dangkal di mana salinitas relatif rendah sedang ikan cakalang berukuran besar membutuhkan salinitas yang lebih tinggi, suhu dan kedalaman perairan yang sesuai. Schaefer dan Fuller (2013) menguraikan bahwa ikan cakalang berukuran relatif besar memiliki kebiasaan menjauhi rumpon atau menyelam ke kolom perairan lebih dalam pada siang hari. Kantun et al. (2014a dan 2014b) menjelaskan bahwa kedalaman lokasi rumpon berpengaruh terhadap struktur ukuran ikan tuna madidihang yang tertangkap dimana ukuran ikan yang tertangkap pada rumpon laut dalam relatif lebih besar dibanding rumpon laut dangkal. Hal lain yang menyebabkan menurunnya tingkat keberlanjutan teknologi penangkapan ikan cakalang di perairan Teluk Bone adalah tertangkapnya biota laut dilindungi. Lopez et al. (2016) menjelaskan bahwa selain ikan cakalang sangat banyak jenis ikan yang berasosiasi dengan rumpon. Mallawa (2016a) bahwa selain ikan cakalang, ikan tuna sirip kuning, tongkol, ikan hiu dapat tertangkap di area rumpon. Gaertner et al. (2015) menjelaskan bahwa penggunaan alat bantu pengumpul ikan (FADs) meningkatkan jumlah tangkapan sampingan (by catch) pada pukat cincin tuna.

Koya et al. (2012) melaporkan bahwa ikan cakalang tertangkap di perairan Samudera Hindia, terdiri atas tiga kelompok umur dan didominasi oleh ikan berukuran kecil atau ikan muda. Chassot et al. (2014) menjelaskan bahwa peningkatan jumlah alat bantu penangkapan ikan (rumpon) yang mengikuti peningkatan jum-lah pukat cincin di Samudera Hindia menimbul-kan banyak permasalahan dan perlu pengelola-annya. Permasalahan berkaitan dengan pe-nangkapan ikan menggunakan alat bantu pe-ngumpul ikan (FADs) antara lain rumpon dapat menjadi perangkap ekologi bagi ikan tuna cakalang (Hallier dan Gaertner 2015), kelebih-an tangkap (over fishing), ikan muda dominan dalam hasil tangkapan (recruitment over fishing), meningkatnya jumlah hasil tangkapan sampingan (by catch), tertangkapnya ikan dilindungi seperti penyu, ikan hiu dan juvenile (Morgan 2011), selanjutnya dilaporkan bahwa persentase spesies non target pada penangkapan ikan cakalang di daerah rumpon $(1,64 \%)$ lebih tinggi dibanding di luar rumpon (0,14\%). Govinden et al. (2013) menjelaskan bahwa ikan cakalang/tuna memiliki kebiasaan mengelilingi benda terapung di laut termasuk rumpon yang dipasang oleh manusia. sehingga pengelolaan rumpon perlu dilakukan. Harley et al. (2009) menjelaskan bahwa untuk mengurangi intensifnya penangkapan ikan dapat dilakukan melalui pelarangan pemasangan baru dan atau pengembangan model baru alat pengumpul ikan yang lebih ramah lingkungan, sedangkan Fonteneau et al. (2015) menjelaskan bahwa salah satu cara pengelolaan FAD adalah mengurangi jumlah terpasang di perairan. Strategis pengelolaan rumpon antara lain pelarangan, penyesuaian kedalaman, penyesuaian jumlah dan sebagainya. Penggunaan rumpon selain aspek negatif seperti yang diuraikan di atas juga namun memberi manfaat bagi nelayan. Gigentika et al. (2014) menjelaskan bahwa penggunaan rumpon dapat menghemat penggunaan bahan bakar minyak oleh nelayan. Cabral et al. (2014) menjelaskan bahwa penggunaan alat bantu pengumpul ikan (FADs) dapat meningkatkan jumlah hasil tangkapan tetapi dapat menyebabkan kegiatan perikanan terpuruk apabila pemakaiannya tinggi sehingga perlu dimbangi melalui upaya pengayaan stok.

\section{KESIMPULAN}

Teknologi penangkapan ikan cakalang di perairan Teluk Bone yang memiliki tingkat keberlanjutan/keramahan lingkungan tinggi atau ramah lingkungan terhadap populasi ikan cakalang yaitu huhate dan pancing tangan yang melakukan penangkapan melalui perburuan gerombolan ikan. Teknologi penangkapan ikan cakalang memiliki tingkat keberlanjutan sedang atau cukup ramah lingkungan yaitu huhate yang melakukan penangkapan di area rumpon dan pukat cincin yang melakukan penangkapan melalui perburuan gerombolan ikan. Teknologi penangkapan ikan cakalang yang memiliki tingkat keberlanjutan rendah atau tidak ramah lingkungan yaitu pukat cincin yang melakukan penangkapan di area rumpon dan payang yang juga melakukan penangkapan cakalang di area rumpon. 


\section{SARAN}

Untuk meningkatkan tingkat keberlanjutan/keramahan lingkungan teknologi penangkapan ikan cakalang di perairan Teluk Bone sebaiknya menghindari penggunaan rumpon dalam pengoperasian alat tangkap atau melakukan pengaturan penggunaan rumpon seperti pembatasan jumlah rumpon dan pemasangan rumpon di perairan yang lebih dalam.

\section{UCAPAN TERIMA KASIH}

Ucapan terima kasih kepada Kemenristek Dikti atas pembiayaan penelitian dan Dinas Perikanan serta nelayan penangkap ikan cakalang se WPP RI 713 atas bantuan dan kerjasamanya selama penelitian ini dilakukan.

\section{DAFTAR PUSTAKA}

Alamsyah R, Musbir, Faisal A. 2014. Struktur Ukuran dan Ukuran Layak Tangkap Ikan Cakalang (Katsuwonus Pelamis) di Perairan Teluk Bone. Jurnal Sains dan Teknologi. 14(1): 95-100.

Ashida H, Tanabe T, Suzuki N. 2009. Recent Progress on Reproductive Biology of Skipjack Tuna in Tropical Region of the Western and Central Pacific Ocean. Scientific Comitte Fifth Regular Session, Port Vila, Vanuatu.

Cabral RB, Alino PM, Lim MT. 2014. Modelling the Impact of Fish Aggregation Device (FADs) and Fish Enhancing Devices (FEDs) and Their Application for Managing Small Scale Fishery. ICES Journal of Marine Sciencesm. 71(7): 17501759.

Chassot E, Goujon M, Maufroy A, Cauquil P, Fonteneau A, Gaertner D. 2015. The use of Artificial Fish Aggregation Device By French Tropical Tuna Purse Seine Fleet. Historical Perpective and Current Practice in Indian Ocean. IOTC-2014WPTT16-20 Rev-1.

Davies TK, Mess CC, Gulland, EJM. 2014. The Past, Present and The Future use of Drifting Fish Aggregation Device in The Indian Ocean. Elsevier : Marine Policy. 45(2): 163-170.

Fonteneau A. 2015. On The Recent Steady Decline ff Skipjack Caught By Purse Seiner in Free Schools in The Eastern Atlantic and Western Indian Oceans.
Collect. Vol,Sci.Pap. ICCAT. 71(1): 417425.

Fonteneau A, Chassot E, Gaertner D. 2015. Managing Tropical Tuna Purse Seine Through Limiting the Number of Drifting Fish Aggregation Device in the Atlantic: Food for Though. Collect.Vol.Sci.Pap. ICCAT. 71(1): 460-475.

Gaertner D, Azis J, Bez N, Clermidy S, Mpreno G, Marua H, Soto M. 2015. Catch, Effport, Ecosystem Impacts of FAD-Fishing. Collect.vol.Sci.Pap.ICCAT. 71(1): 525-539.

Garbin T, Castello JP. 2014. Changes in Population Structure and Growth of Skipjack Tuna, Katsuwonus pelamis, During 30 Years of Exploitation in the Southwestern Atlantic. Lat.Am. J. Aquatic Res. 42(3): 534-546.

Gigentika S, Wisudo SH, Mustaruddin. 2014. Strategi Pengembangan Perikanan Cakalang (Katsuwonus Pelamis) di Kabupaten Lombok Timur Provinsi Nusa Tenggara Barat. Marine Fisheries. 5(1): 2740.

Govinden R, Jauhari R, Filmalter J, Forget F, Soja M, Adam S, Dagorn L. 2013. Movement Behavior of Skipjack (Katsuwonus pelamis) and Yellowfin (Thunnus albacores) Tuna at Anchored Fish Aggregation Devices (FADs) Investigated by Acoustic Telemetry. Aquat. Living Resou. 26: 69 - 77.

Harley S, William P, Hampton J. 2009. Analysis of Purse Seine Set Times for Different School Association. A Futher Tools to Assist in Compliance with FAD Closure. Fifth Regular Session of the WCPFC Scientific Committee Aug 10 21, 2009. Port Villa, Vanuatu.

Hallier JP, Gaertner D. 2008. Drifting Fish Aggregation Devices Could Act as Ecological Trap for Tropical Tuna Species. Marine Ecology Progress Series. 353: 255-264.

Itano DG. 2011. The Reproductive Biology ff Yellowfin Tuna (Thunnus albacore) in Hawaiian Waters and the Western Tropical Pacific Ocean : Project Summary. Joint Institute for Marine and Atmospheric Research and NOAA. USA.

Jamal M, Sondita FA, Wiryawan B, Haluan J. 2014. Konsep Pengelolaan Perikanan Tangkap Cakalang (Katsuwonus pelamis) di Kawasan Teluk Bone Perpektif Berkelanjutan. Jurnal IPTEKS Peman- 
faatan Sumberdaya Perikanan. 1(2): 196 $-207$.

Kantun W, Mallawa A, Rapi NL. 2014a. Perbandingan Struktur Ukuran Tuna Mandidihang (Thunnus albacores) yang Tertangkap pada Rumpon Laut Dalam dan Laut Dangkal di Perairan Selat Makassar. Jurnal IPTEKS Pemanfaatan Sumber daya Perikanan. 1(2): 112-128.

Kantun W, Mallawa A, Rapi NL. 2014b. Struktur Ukuran dan Jumlah Tangkapan Tuna Mandidihang (Thunnus Albacores) Menurut Waktu Penangkapan dan Kedalaman di Perairan Majene Selat Makassar. Jurnal Saintek Perikanan. 9(2): 39-48.

Koya KPS, Joshi KK, Abdussamad EM, Rohit P, Sebastine M. 2012. Fishery, Biology and Stock Structure of Skipjack Tuna, Katsuwonus pelamis, Exploited from Indian Waters. Indian J.Fish. 59(2): 3947.

Lopez A, Martin E, Maria C. 2016. A Model Based on Data from Echosounder Buoys for Estimate of Fish Species Associated with Fish Aggregation Device. Fishery Bulletin.14(2): 166-178.

Mallawa A, Musbir, Amir F, Marimba AA. 2012. Analisis Struktur Ukuran Ikan Cakalang (Katsuwonus Pelamis) Menurut Musim, Daerah Penangkapan, dan Teknologi Penangkapan di Perairan Luwu, Teluk Bone Sulawesi Selatan. Jurnal Sains dan Teknologi. 3(2): 29-38

Mallawa A. 2013. Dinamika Populasi dan Pendugaan Stok. Bagian I : Dinamika Populasi Biota Perairan. Buku Ajar, LKPP UnHas. Makassar.

Mallawa A, Amir F, Zainuddin M. 2014. Keragaan Biologi Populasi Ikan Cakalang (Katsuwonus Pelamis) yang Tertangkap dengan Purse Seine pada Musim Timur di Perairan Laut Flores. Jurnal IPTEKS Pemanfaatan Sumberdaya Perikanan. 1(2): 129-145.

Mallawa A. 2016a. Persentase Ikan Cakalang (Katsuwonus Pelamis) Layak Tangkap Hasil Tangkapan Nelayan di Perairan WPP RI 713. Prosiding Simposium Na- sional Kelautan dan Perikanan. 3: 547554.

Mallawa A. 2016b. Size Structure of Skipjack Tuna (Katsuwonus Pelamis) Captured By Pole and Line Fishermen Inside and Outside of Fish Aggregation Devices at Gulf of Bone Waters, South Sulawesi. International Journal of Scientific and Technology Research. 05(09): 159-163.

Mallawa A, Musbir, Sitepu F, Amir F. 2016. Beberapa Aspek Perikanan Ikan Cakalang (Katsuwonus pelamis) di Perairan Barru, Selat Makassar, Sulawesi Selatan. Jurnal IPTEKS Pemanfaatan Sumberdaya Perikanan. 3: 392-405.

Mallawa A. 2017. Perbandingan Hasil Tangkapan Ikan Cakalang (Katsuwonus Pelamis) Purse Seine yang Dioperasikan di Dalam dan di Luar Area Rumpon. Jurnal Agrokompleks. 16(1): 1-6.

Mallawa A, Amir F, Sitepu FG. 2017. Kajian Kondisi Stok Ikan Cakalang (Katsuwonus Pelamis) di Perairan Teluk Bone, Sulawesi Selatan. Jurnal IPTEKS Pemanfatan Sumberdaya Perikanan. 4(2): 572588.

Morgan AC. 2011. Fish Aggregation Device and Tuna, Impact and Management Option. Ocean Sciences Division, Pew Environment Group, Washington.D.C.

Prayitno MRE, Simbolon D, Yusfiandayani R, Wiryawan B. 2017. Produktivitas Alat Tangkap yang Dioperasikan di Sekitar Rumpon Laut Dalam. Jurnal Marine Fisheries. 8(1): 101-112.

Schaefer KM, Fuller DW. 2013. Simualtaneous Behavior of Skipjack (Katsuwonus pelamis), Bigeye (Thunnus obesus), and Yellowfin ( $T$. albacares) Tunas, Within Large Multi Species Aggregations Associated with Drifting Fish Aggregation Device (FADs) in The Equatorial Eastern Pacific Ocean. Mar.Biol. 160(1): 30053014.

Wang X. Xu L, Chen Y, Zhu G, Tian S, Zhu J. 2012. Impact of Fish Aggregation Deviceson Size Structures of Skipjack Tuna (Katsuwonus Pelamis). J. Aquat. Ecol. 46(2): 343-352. 